\title{
Carles Bas i Peired
}

\author{
FRANCESC SARDÀ \\ Institut de Ciències del Mar, CSIC, Pg. Marítim de la Barceloneta 37-49, 08003 Barcelona, Catalunya, Spain.
} E-mail: siscu@icm.csic.es

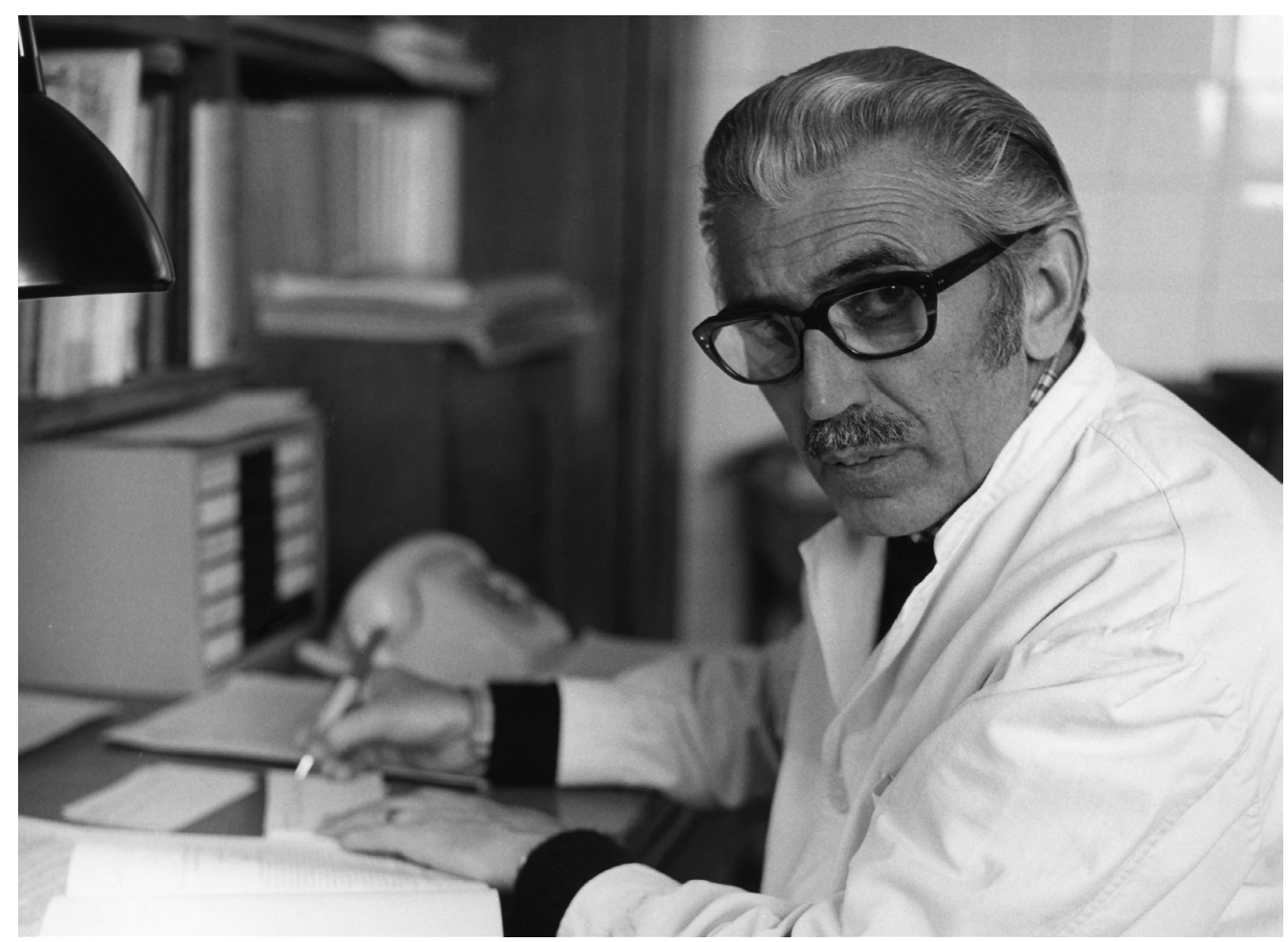

Carles Bas i Peired was born in a Catalan family in Barcelona in 1922. From his childhood he showed a great vocation as a naturalist, making regular visits to the Zoological Park of Barcelona with his father. One of the first presents he remembers with emotion was a book about animals. This passion for the observation of nature led him to keep a notebook for drawing and pasting pictures of animals, to which he would add an explanation of the animal's feeding patterns or behaviour.
Carles Bas went to school at the Escolapis de San Antoni in Barcelona. His education was interrupted by the Spanish Civil War, but when the war ended he was able to continue. He started a degree in Natural Sciences at the University of Barcelona in 1942. He studied alongside several others who would become outstanding natural scientists, such as Oriol de Bolòs, Manuel Gómez-Larrañeta, Pere Oliver, Enrique Morales and Rosario Nos (with the latter he shared the University Degree Extraordinary Prize in 1946). At the 
beginning of his degree course, Bas was attracted by botany. A grant from the Montjuïc Botanical Institute allowed him to start to do research, and very soon he was publishing papers in this discipline. Thanks to contacts with Enrique Gadea and especially with Francisco García del Cid, then a professor at the University of Barcelona, in 1949 Bas joined the Marine Biology section of the Spanish National Research Council (Consejo Superior de Investigaciones Científicas, CSIC) at the laboratory in Blanes (Girona). Interested in growth and morphometry, Bas wrote a pioneering $\mathrm{PhD}$ dissertation on the biology of the Atlantic mackerel Scomber scombrus (Universidad de Madrid, 1953).

Bas had his first contact with the sea in his friendly conversations with the fishermen of Blanes harbour. Aware of his limited knowledge of fisheries, he soon understood that the contacts with fishermen would provide him not only with basic biological knowledge but also with knowledge of the social reality of fishing. The biography of a person is often linked to that of other people, and Bas talks with respect as a person and professional about Tomàs, an old fisherman from Blanes. During their long conversations, Bas linked science and popular knowledge, and what is more important, learned to recognize the technical concepts of fisheries and the importance of being in the field and on board.

Bas concluded this period with a trip along the whole Catalan coast. The result of this trip was a classic and fundamental book for understanding fisheries in Catalonia, La Pesca en España. I Cataluña (Patronato Juan de la Cierva, CSIC. 1955), which he wrote with his colleagues of the time, Manuel Rubió and Enrique Morales. This book is still now regularly consulted. It was at this time that I think Bas generated the internal energy that would drive him for the rest of his career in the study of marine resources.

In 1962 he moved to the Institute of Fisheries Research (Instituto de Investigaciones Pesqueras, IIP), where he coincided with Bonaventura Andreu and Ramon Margalef. At the Institute he also met Fernando Lozano from the Spanish Institute of Oceanography (Instituto Español de Oceanografía, IEO), with whom he undertook a project in which fisheries and environment were considered together for the first time. During his conversations with Margalef in the late 1960s, Bas was encouraged to strongly promote the study of fisheries resources and their internationalization to Saharan waters, but from the start he felt it was important to do this from a fundamentally dynamic and environmental perspective. The relationships between fisheries and the environment has always fascinated Bas who, thanks to his tireless efforts to obtain funding from the Directorate General of Fisheries, started to study in Southern Africa, at the Sahara bank and in the Mediterranean Sea with colleagues on board factory, fishing and scientific vessels. During this period Bas participated in the planning and strategy for the construction of the first Spanish oceanographic vessel, the R/V Cornide de Saavedra, under

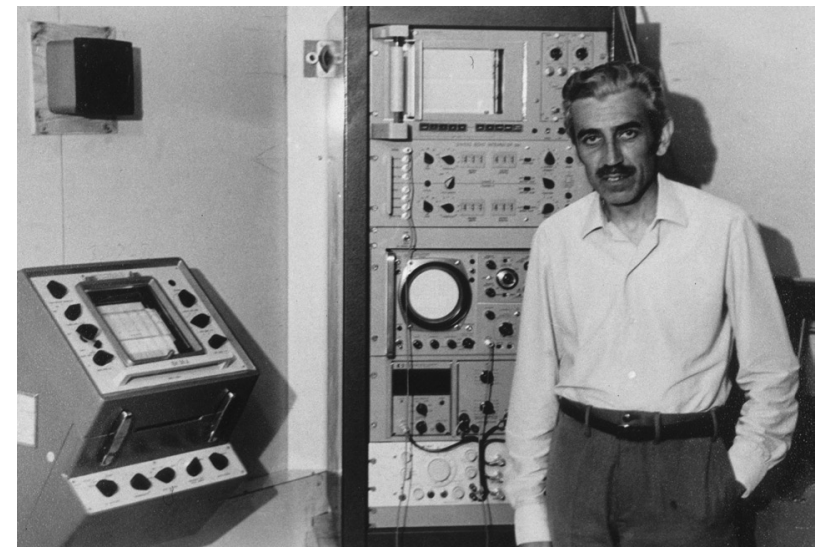

Carles Bas with a Simrad EK scientific echosounder on board R/V Cornide de Saavedra during the Sahara I cruise (1971).

the auspices of the Juan de la Cierva Board of Scientific and Technical Research and funded by the Spanish Development Plans.

Bas then entered a second stage that could be considered one of scientific expansion and fulfilment. Between 1975 and 1994 he carried out the major projects named above, organized international meetings on fisheries, environment and economics, supervised several $\mathrm{PhD}$ dissertations (over 20) and became well-known in South America as a lecturer. We should mention a series of positions and responsibilities that Bas undertook over two decades. I highlight here some of the most important: he was vice-president and president of the Marine Resources Committee of the Food and Agriculture Organisation - General Fisheries Commission for the Mediterranean (FAO-GFCM) (1962-1964 and 1972), vice-president and president of the Catalan Society of Biology (1973-1979), special commissioner of UNESCO in Mauritania, Encomienda de la Orden del Mérito Civil (1973), president of the Scientific Advisory Council of International Commission for South East Atlantic Fisheries (1977), president of the National Centre of Fisheries Research (1980), winner of a medal in the Fisheries Award of the Catalan Government (1990), special commissioner in Uruguay for the Intergovernmental Oceanographic Commission of UNESCO and the United Nations Development Programme (1990), honorary rector of the Aulas del Mar of the University of Murcia and honorary doctor of the University of Las Palmas of Gran Canaria (2005). Following this remarkable career, Bas has obtained several recognitions, special awards and tributes. We should also highlight the major role that he played in the construction of the first mid-range oceanographic vessel of the CSIC, the R/V García del Cid. Finally, it is worth mentioning the report he presented for his induction in the Royal Academy of Sciences and Arts of Barcelona, communicated in 1990 and at the inaugural session of the 2007-2008 academic year at the same institution.

To understand Bas as a scientist, we need to go back to his time, when democracy in Spain had just 


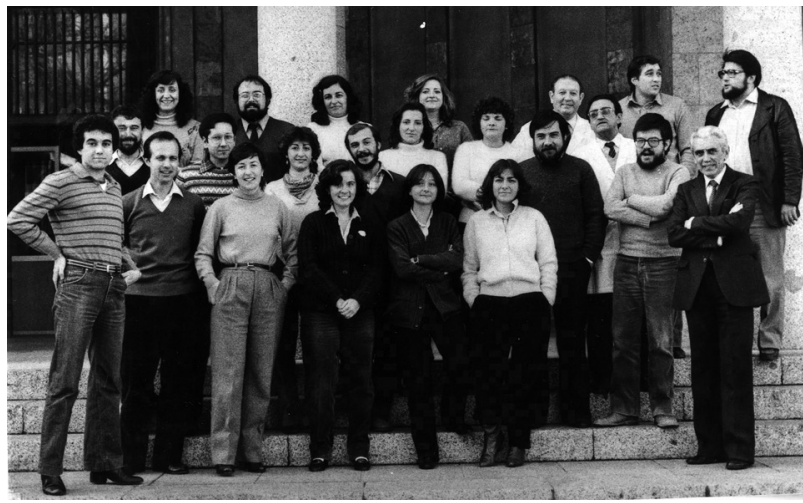

Carles Bas with members of the fisheries department in front of the ICM (1987).

begun and national fisheries were expanding greatly. Bas has been an active scientist: one of field research, management, organisation and education. He taught us that understanding fisheries means going to the level of the fishing vessels, the field, the fishermen, the fish market. All this results in a systematic education that includes the environment, economy and sociology for the understanding of the system (as is shown by his organisation of two international congresses in this topic). He got to know the main issues of the major western fisheries of Namibia, South Africa, the Spanish Sahara, South America and, of course, the Mediterranean Sea. He visited many countries and attended and directed international forums as well as scientific and management meetings.

To understand Bas as a person, we could say that he has two families that are not that different from each other: his blood family and his scientific family. These two families always walk in parallel, sharing a certain symmetry for one specific reason: Bas believes firmly in young people. He has seven children and has trained over 30 researchers at the Institute of Marine Research (Institut de Ciències del Mar, ICM) in Barcelona and in the Canary Islands. And between these two big families there was always his efficient and discreet wife, Mercè Calvó, who has allowed Bas to combine his family life and research without them interfering with each other.

In order to carry out his research, Bas trained and trusted a large number of young researchers whom he supported from early on. Training and trust are the key words. I remember the courses that Bas gave from the early 1970s onward and his constant encouragement and motivation of young people by giving them responsibilities and promoting their initiatives. This does not mean that he was condescending: it could even be said that he was strict and rather blunt. When things went wrong, he would say three times the definitive words that encapsulated his spirit: "work, work and work". As the coordinator of several projects, Bas promotes team work involving his group and supporting different points of view, while taking advantage of the specific personal characteristics and scientific skills of each person to attain the main objectives of the projects.
After his period as director of the ICM, Bas went to the University of Palmas de Gran Canaria (1987-1995) to start forming a now well-established research group on marine resources, for which he received an honorary doctorate from that university in 2005 . For reasons of space I will not dwell further on this period that he spent away from his roots in Barcelona and Catalonia.

When Bas left the Canary Islands, he returned to the ICM, where we have benefited from his presence until today, in what I call his "second retirement". Since then, Bas has dedicated his time to reading, studying and compiling experiences and knowledge of his whole scientific career. He can often be found in the Institute's library. During this last stage, he has undertaken scientific studies with his colleagues from the Canary Islands, developing dynamic models for fisheries linked to the environment, without forgetting the economics and sociology related to the exploitation of resources. Other results of this compilation of a life dedicated to marine sciences have been his latest books, among which we find The Mediterranean sea: living resources and exploitation (Zaragoza, CIEHAM-IAMZ/FAO COPEMED. 2005), without doubt a reference for an up-to-date, synoptic vision of the Mediterranean Sea.

\section{DIRECTORSHIP (1983-1987)}

In 1983, Carles Bas was nominated director of the Institute of Fisheries Research of Barcelona, in replacement of Bonaventura Andreu.

When Bas became director of the IIP he was already president of the CENIP, the structure created in 1979 to bring together the common services of all the CSIC institutes dedicated to marine research that were independent from the central Barcelona Institute: research vessels, the journals publishing board and a commission for the coordination of the institutes. This post involved Bas in the management of the IIP well in advance, so when he took over he already had sound experience. During his directorship, an outline of what the new institutions would be after a major renovation started to emerge. Through this renovation the IIP was converted into the current ICM, including a Marine Geology group under the responsibility of Andrés Maldonado, formerly at the Institute of Earth Sciences (Instituto de Ciencias de la Tierra, IJA) also within the CSIC. All these changes originated from the central CSIC organisation in Madrid, under the direction of its president Enrique Trillas and with the close collaboration of Josefina Castellví and Antoni Ballester. Bas faced a very important challenge during his directorship: the transformation of the institution into a modern research centre integrated in the European Community. This was not an easy task and his period as director was somewhat turbulent. He himself recognizes that after a very satisfactory stage in his career he was sometime involved in too much infighting, pressure and misunderstanding. 
If we had to identify the mark left by Bas during his phase as director, I would highlight the opening to Catalan society and the increasing visibility of the Institute and other scientific groups such as the Interdepartmental Commission of Research and Technology of the Catalan Government (CIRIT), which gave so many good results during the following years in terms of financial support. As director, Bas established contacts, agreements and cooperation with the Spanish Institute of Oceanography (with which the relationship had not previously been very good), the Social Fund of La Caixa, the University of Barcelona, the Universitat Autònoma de Barcelona and the Universitat Politècnica de Catalunya (with which he helped to create a doctoral degree in Marine Sciences), the Bosch i Gimpera Foundation and the Metropolitan Consortium. At this time, the Institute was visited by the Catalan president, Jordi Pujol, and by the former Spanish Minister of Education and future Director-General of UNESCO, Federico Mayor Zaragoza, among other representatives of the political and social spheres.

Bas then became a powerful manager, consolidating the Renewable Marine Resources Group and strongly promoting the Oceanography Group. He strengthened and gave content to the Institute's management (basically a scientific board), laying the bases for the democratic normalization of future appointments to the post of director. He used his contacts with funding institutions to provide analysis and sampling equipment and personnel for the departments and services. He promoted and modernized the library, the electronic microscope, the biological collections and the computing centre. During his directorship, the Institute prepared itself to face the new research challenges in the framework of the European Community. This implied a significant updating of computer systems and modern sensors. Bas managed most of this equipment through the CIRIT and through personal negotiations directly with the Spanish central government institutions.

Well aware of the importance of outreach, Bas promoted the Institute with an exhibition at the Maritime Museum, a stand at the Nautical Fair and open days at the laboratory, among others. It is important to mention all these activities to understand the mark that he left in the Institute, through his dynamism, his promotion at all levels and the personal qualities that he used to seek funding for the human and technical resources. We can say without doubt that Bas situated the Institute in the current research line, making it more democratic, more modern and better structured. All this is took place at a time of a major political and social transformation when Spain entered the European Community (the Adhesion Treaty was signed in June 1985). As a director, he was able to exploit the situation. Carles Bas finished his mandate as director when he retired in 1987.

\section{ACKNOWLEDGEMENTS}

I wish to thank Jordi Salat for his critical revision of the draft and Eva Ramírez for translating the text. Thanks are also due to Isabel Palomera, Joan Navarro and Samuele Tecchio for their general comments on the manuscript, and to Elisabetta Broglio for helping me to find the photographs.

\section{BIBLIOGRAPHY}

Bas C. 2009. Pregó Festa Major de Blanes. RECVLL, núm. 1989.

Bas C., Castro J.J., Lorenzo J.M. (eds.). 1995. International Symposium on Middle-sized Pelagic Fish. Sci. Mar. 59(3-4) in the Foreword.

Biblioteca de Ciencias Básicas "Carles Bas" 2011. Homenage al Dr. Carles Bas Peired, 16 Mayo, 2011. Universidad de Las Palmas de Gran Canaria. http://bibwp.ulpgc.es/carlosbas/2011/05/16/ homenaje-al-dr-carlos-bas-peired.

Guerra A., Prego R. 2003. El Instituto de Investigaciones Pesqueras: Tres décadas de historia de la investigación marina española. Estudios sobre la ciencia: 33. Consejo Superior de Investigaciones Científicas. $341 \mathrm{pp}$.

Institut d'Estudis Catalans. Carles Bas i Peired Membres numeraris i emèrits <http://www.iec.cat/institucio/entrada. asp?c_epigraf_num $=4001>$

ICM (CSIC). 2010. Dr. Carles Bas i Peired. Impulsor del Departament de Recursos Marins Renovables (ICM-CSIC). Poster.

La Recerca Oceanográfica a Catalunya. "El doctor Bas, un puntal dins l'oceanografia". D, entrevista: 59-64.

Biography series ed.: F. Peters. 